\title{
Jak ve sportu pomáhá představivost?
}

\section{How does imagery help in sport?}

\author{
Veronika Kavková1, Marek Malůš², Jitka Taušová ${ }^{2}$, Hana Válková ${ }^{1}$ \\ ${ }^{1}$ Fakulta tělesné kultury, Palackého univerzita v Olomouci \\ ${ }^{2}$ Filozofická fakulta, Palackého univerzita v Olomouci
}

\begin{abstract}
Abstrakt
Př́spěvek pojednává o možnostech využití představivosti (imaginace) ve sportu v rámci zlepšování výkonnosti psychologickými prostředky. Tato mentální technika je často využivána sportovci ke zlepšení jejich sportovního výkonu. Jako intervenčni techniku ji využivaji pro své svěrence sportovní psychologové a $v$ poslední době i trenérí. Tréninkový plán imaginace v rámci sportovní psychologické př́pravy je v zahraniči široce rozpracován. Technikou imaginace se v oblasti psychologie sportu zabývá stále více výzkumniků. Její podstatou je vytvárení co nejkvalitnějších a nejživějšich představ o úspěšném vykonání toho, co chceme na svém výkonu zlepšit. Př́rspěvek se zabývá teoretickými aspekty procesu imaginace, jeho charakteristikou, členěním a
\end{abstract} podrobnými aspekty využití u sportovní populace.

\section{Abstract}

This paper deals with the possibilities of using imagery (imagination) in sports to improve performance by psychological means. This mental technique is often used by athletes to improve their sports performance. It is also used as an intervention technique by sports psychologists and more recently coaches for athletes. Abroad, the Training schedule of imagery in sports psychology training is widely developed. The numbers of researchers dealing with the technique of imagery in sport psychology is rising. The essence is to create a mental image of highest quality, and a vivid picture of successful execution of what we want to improve in our performance. This paper deals with the theoretical aspects of the imagery, its characteristics, structure and detailed aspects of the use in sports.

Klíčová slova: představivost, imaginace, mentální trénink, vizualizace, psychologie sportu

Key words: imagery, imagination, mental training, vizualization, sport psychology

Tento článek vznikl za podpory specifického vysokoškolského výzkumu IGA 2012: FTK_002

\section{ÚVOD}

Výkon ve sportu představuje nadstandardní zátěžovou situaci. Rozdíly ve fyzické připravenosti závodníků jsou mnohdy velmi malé, a proto se poslední dobou na scénu dostávají techniky pracující s psychikou sportovce. Psychická připravenost závodníků může hrát důležitou roli. Na vyšší výkonnostní úrovni představuje oblast psychiky největší rezervu v tréninku, nebot' úspěšní sportovci se liší od méně úspěšných tím, jak rozvinuté jsou jejich psychologické dovednosti. V rámci psychologických intervencí pro sportovce, ale i u koučování se při zvyšování výkonu pracuje s mentálními technikami. Tou nejužívanější v psychologii sportu je představivost neboli imaginace (Morris et al., 2005). 


\section{Představivost neboli imaginace}

Pojem imaginace pochází z latinského ,imago“ - obraz a „vyjadřuje komplexní proces seskupování představ do určitých struktur a jejich fungování“ (Nakonečný, 2004, s. 136).

Nejedná se tedy o pouhou vizualizaci, kdy je do představ zapojena jen zraková modalita. Cílem představivosti je zapojit do představy co nejvíce smyslů tak, aby se nejvíce přiblížila realitě. Tak to ve své definici imaginace popisují White a Hardy (1998 in Singer et al., 2001, s. 529): „Imaginace je prožívání, které napodobuje skutečnou praxi. Můžeme si uvědomovat vidění určité vytvořené představy, cítění pohybů jako utvořenou představu, nebo si zkusit představit čichové vjemy, chut' anebo zvuky bez toho, že bychom byli vystaveni působení podnětů, které tyto vjemy způsobují. Někdy pomůže zavřít oči. Liší se to od snů, ze kterých jsme probuzeni, ale uvědomujeme si, kdy utváríme představu.“

Tento proces zahrnuje vyvolávání jednotlivých informací uložených $\mathrm{v}$ paměti z již zažité zkušenosti a utváření smysluplné představy z těchto informací. Jednotlivé informace jsou v podstatě produktem naší paměti, vnitřně zažité znovu-vyvoláním a rekonstrukcí předešlých událostí. Imaginace je vlastně forma simulace (Watt et al., 2006).

\section{Specifika imaginace ve sportu}

O pozitivním vlivu imaginace na výkonnost ve sportu byla napsána řada studií (Weinberg et al., 2003; Short et al., 2005; Short et al., 2006; Weinberg, 2008). Předpokladem úspěšné imaginace je vytvoření kvalitní, přesné představy, která ovlivňuje senzomotorickou aferenci, a tím dosahuje změnu v pohybovém vzorci chování (Slepička et al., 2006). Nejprve je určena dovednost, která má být zlepšena, naučena či přeučena. Ta je následně v relaxovaném stavu nacvičována tak dlouho, dokud nemá sportovec jasnou představu daného pohybu. Jednou z nejvíce uznávaných teorií o tom, jak funguje imaginace při osvojování si motorických dovedností, je tzv. Carpenterova psychoneurosvalová teorie. Podle této teorie imaginace funguje na základě vytváření nervových spojů pro motorickou činnost v mozku. Při dobře prováděné imaginaci se v mozku zapojují stejná centra jako při reálném provádění úkonu, pouze v menší míře (Carpenter, 1894; in Singer et al., 2005). „Tato zpětná vazba umožňuje přizpůsobení motorickému chování nebo napomáhá počtu mentálních uzlů, které cvičenec aktivuje a které představují požadované motorické chování během výkonu.“ (Morris et al., 2005, s. 305).

V rámci využití ve sportu lze imaginaci rozdělit podle několika kritérií:

\section{Kognitivní / motivační}

Tyto dva typy imaginace vycházejí z funkcí imaginace dle Paivia (1969; in Singer et al., 2001). Ten rozlišuje dvě funkce imaginace: motivační a poznávací. Co se týče motivační imaginace, mohou ji sportovci užívat k představování si specifických cílů a k účelově zaměřenému cíli, jako je například vítězství v určité soutěži nebo představa ocenění za dobrý výkon. Tyto pozitivní představy sportovce povzbudí, dodají mu sebevědomí, a on jde pak s tímto naladěním do závodu či hry. Co se týče kognitivní imaginace, zaměřje se na zlepšování či nácvik specifických motorických dovedností, ale i celých herních strategií. Je to ten typ imaginace, který je používán, když se sportovci snaží získat ,pocit pohybu“ a zlepšit svou úroveň motorické dovednosti. Většina výzkumů ukazuje efektivitu tohoto typu mentální imaginace na zlepšení výkonu (Hardy, Callow, 1999; Weinberg et al., 2003; Short et al., 2005).

\section{Interní / externí}

Pro promítnutí své imaginace sportovci obvykle volí bud' vnitřní (interní) nebo vnější (externí) perspektivu. Vnitřní imaginace je definována jako zraková představa sebe sama v první osobě (Hardy, Callow, 1999). Jako kdybychom měli na hlavě kameru, uvidíme pouze to, co je vidět, když právě provádíme určitou dovednost. Protože vnitřní imaginace pochází ze zorného pole nás samých, obrazy zdůrazňují pocit pohybu. Vnější imaginace je definována jako zraková představa sebe sama ve třetí osobě (Hardy, Callow, 1999). Když používáme vnější imaginaci, vidíme se z pozice vnějšího pozorovatele. Je to, jako kdybychom se dívali v kině na film nebo na videokazetu.

Základní Hallovy studie potvrzují, že špičkoví sportovci upřednostňují vnitřní perspektivu, ale jiní výzkumníci toto tvrzení nepotvrdili (Hall, 2001 in Singer et al., 2001). Ve skutečnosti většina sportovců užívá jak vnitřní, tak vnější imaginaci. Hardy tvrdí, že vnější imaginace má lepší vliv na získání dovednosti a její 
provedení. U vnitřní perspektivy se předpokládá, že bude lepší k osvojení a k výkonu požadovaných dovedností, které velkou měrou závisí na vnímání a anticipaci (Hardy, 1999; in Singer et al., 2001).

\section{K čemu lze imaginaci ve sportu využít}

\subsection{Učení se a nácvik dovedností}

Jedním z nejčastějších využití imaginace je mentální procvičování sloužící k učení se a nácviku určité motorické dovednosti (Morris et al., 2005). Užití imaginace tímto způsobem dovoluje sportovcům učit se a udržovat technické dovednosti pro svůj sport (Hardy, Callow, 1999; Williams, 2006). Imaginace může být použita samotná k mentálnímu nácviku dovednosti nebo může být kombinována s fyzickým cvičením. Fyzický trénink může odhalit problémy vyžadující změny pohybu původně představovaného. V takových př́padech je vhodný další imaginační nácvik co nejdřív upravené dovednosti (Weinberg et al., 2003). Představa učení se motorické dovednosti a její procvičování by měla zahrnovat hlavní elementy aktivity spolu s detaily, které učiní imaginaci realističtější (jako jsou smyslové podněty a pohybová kvalita). Dokonalá vizualizace všech detailů je nezbytnou součástí zvládnutí daného pohybu. Stejně jako opakovaně procvičujeme dovednosti, abychom si je udrželi, tak také můžeme pomocí tréninku posílit dovednost již dobře propracovanou (Morris et al., 2005). Na profesionální úrovni není časté učit se novým dovednostem, ale procvičování již získané dovednosti je cenné pro udržení její kvality. Ačkoli mentální trénink nikdy nemůže nahradit fyzické cvičení, je velmi efektivní jej s fyzickým tréninkem kombinovat.

\subsection{Taktické a herní dovednosti}

Sportovci mohou použít imaginaci jako prostředek k rozvoji nebo vytvoření nových strategií, k získání nejlepších výkonů svých nebo týmových, k rozvoji herních plánů pro boj se specifickými protivníky ještě předtím, než půjdou do soutěže (Singer et al., 2001). Zkušení sportovci, zvláště ve sportech s plastickými dovednostmi, potřebují být schopni rozvíjet různorodé strategie. Potřebují být schopni myslet př́mo nebo si představit nejlepší strategie pro své či týmové výkony. Vytváření představ toho, co potřebujeme udělat, a možných alternativ může sportovcům pomoci učinit správné rozhodnutí v plánování jejich výkonů. Imaginace může být tímto způsobem použita jako forma plánování výkonů. Např́klad hokejista nebo fotbalista si mohou představit různé defenzívy, kterým budou čelit, a hry, které mohou použít k jejich průlomu. Fotbalový tým se může sejít na poradu během týdne, který zbývá do zápasu, a použít imaginaci jako pomoc pro vytvoření herních plánů. Trenéŕi mohou používat imaginaci k rozvoji nových her předtím, než je důkladně vyzkouší na tréninku nebo $\mathrm{v}$ zápase. Jakmile byly vytvořeny nové strategie, mohou sportovci použít imaginaci $\mathrm{k}$ jejich nácviku a pokusit se je naučit před soutěží. K seznámení s rolemi svých spoluhráčů a chápání, jak sladit svou úlohu s druhými, může každý člen použít imaginaci ke zvýšení výkonu své nové strategie (Morris et al., 2005).

\subsection{Soutěž a výkon}

Sportovci také mohou imaginaci použít k př́ipravě na jednotlivé soutěže nebo k přemýšlení o soutěži poté, co již proběhla (Weinberg, Gould, 2003; Williams, 2006). To znamená, že imaginace může být použita nejen pro trénink, ale také pro výkon a pro soutěž. Aby se sportovci cítili pohodlněji a redukovali rozptýlení den před soutěží, mohou si představit závodění v den konání. Nebo pokud na daném místě již předtím byli, mohou použít svou pamět' ke znovuvytvoření scény ve dnech nebo dokonce týdnech, které zbývají do zápasu či soutěže. Mohli by si představit všechny aspekty svého výkonu a úspěšné provedení svých technických a taktických dovedností v den zápasu. Sportovci mohou zjistit, že imaginace vyvolaná v dějišti utkání je realističtější a omezuje možné rozptýlení z nového prostředí, v němž se člověk nachází v době zápasu (Morris et al., 2005).

\subsection{Psychologické dovednosti}

Imaginace může také ovlivnit sportovcův psychický stav. Může zvýšit psychologické dovednosti, jako je koncentrace, sebevědomí, motivace a kontrola úzkosti (Short et al., 2005). 


\subsubsection{Kontrola úzkosti a zacházení se stresem}

Imaginace může sportovcům pomoci úspěšně se vyrovnat s problémy nebo situacemi, které mohou vyvolávat úzkost (Crust, 2005; Morris et. al., 2005; Williams, 2006). Pomáhá tím, že si tyto problémy připustíme během vytváření plánů a $\mathrm{v}$ představách se $\mathrm{s}$ těmito situacemi vyrovnáváme. Imaginace může být tímto způsobem použita např́klad k vyrovnání se se stresem, který se objevuje vzhledem k náročnosti sportu. Na velký stres se tělo reaguje různými způsoby - zrychleným tlukotem srdce, vysokým krevním tlakem, zpocenými dlaněmi, intenzivnějším dýcháním apod. Tyto pocity dávají prostor pro negativní myšlenky, pochybnosti a strach. Důsledkem je, že často pod tlakem chybujeme, selžeme nebo přinejmenším plýtváme duševní energií. Mnohdy také prohlašujeme, že pro úspěšné zvládnutí nejsme dost silní, uvolnění, nebo máme málo zkušeností. Ve většině prŕípadů je řešení pouze ve stavu naší mysli. Mysl, která je ve stresu, může být těžké najednou změnit. Jediné co můžeme udělat, je nahradit probíhající program v naší mysli lepším, který nám pomáhá se koncentrovat (Slepička et al., 2006).

\subsubsection{Koncentrace a pozornost}

Aby sportovci dosáhli zaměření pozornosti, mohou si představit významné aspekty nadcházejícího výkonu. To zúží zaměření na významné věci, a omezí dopad negativních aspektů. Aby se naučili trvalé koncentraci během výkonu, mohli by si představit nadcházející výkon a všechny potenciální roztržitosti, které mohou být prítomny, a vyvinout copingové strategie k jejich vyrovnání předtím, než se stanou problémem.

\subsubsection{Sebeuvědomění}

Imaginace je široce doporučována jako prostředek k získání sebevědomí. Představy mohou vytvořit pocity kompetence a úspěchu, jako je provedení dobrého výkonu nebo správné vykonání dovednosti, či vzrůst sportovcovy důvěry.

\section{Vyrovnání se se zraněním}

Naše mysl si dokáže představit a zobrazit události, které se ještě neobjevily. Ačkoli imaginace je závislá především na paměti, můžeme si vytvořit představu z několika částí paměti. Např́klad sportovec, který se podrobil rehabilitaci kvůli vymknutému rameni, si může představovat, jak zvedá paži přes hlavu, ačkoli ještě není schopen to udělat. Protože je imaginace mentální aktivita a není spojena s fyzickým pohybem, může být její používání spojeno i se zraněním a těžkým tréninkem (Morris et al., 2005).

Pro sportovce může být velmi obtížné vyrovnat se s dlouhotrvajícím zraněním. Imaginace zde může pomoci vyrovnat se s určitými problémy spojenými s dlouhodobou absencí ve sportu. Jak uvádí Singer (2001), obavou mnoha sportovců v tomto období je, že zůstanou pozadu za dalšími sportovci, kteří jsou schopni trénovat a soutěžit. Během dlouhodobého vysazení kvůli zranění mohou sportovci použít imaginaci pro práci na technických, taktických a psychologických dovednostech spojených s výkonem. K udržení fyzické svěžesti pro návrat do sportu mohou použít imaginaci například jako mentální trénink k učení se novým dovednostem, k procvičování a udržování si již existující dovednosti, když je nemohou provádět fyzicky, nebo k rozvoji, procvičování a učení se strategiím.

Imaginace může být použita k usnadnění uzdravení se ze zranění, obzvláště měkkých tkání. Stejný proces může být použit pro bolest spojenou s těžkým tréninkem. Samotná představa většího krevního toku ke zraněnému místu, stejně jako použití tepla na poškozenou tkáň, může být léčebná. Výzkumníci tak zaznamenali změny v použití imaginace během období rekonvalescence (Lynne et al., 2006). V týdnu následujícím po zranění sportovci udávají, že jim jejich emoce zabraňují použít imaginaci. Potom, během počáteční fáze léčení, udávají, že použivají imaginaci za účelem hojení a hospodaření s bolestí, a kognitivní imaginaci používají k nácviku a udržování dovedností a zvýšení sebevědomí. Ve středové fázi, jako odpověd' na potřebu cítit, že zranění se zlepšuje, vidět zlepšení ve své rehabilitaci a udržet si svou úroveň dovednosti, sportovci obecně hlásí vzrůst kognitivní imaginace. Použití imaginace v této době zvyšuje jejich motivaci k uzdravení a návrat ke sportu. V konečné fázi je užívání imaginace u sportovců omezeno na využití kognitivní imaginace (Driediger, Hall \& Callow, 2006). 


\section{ZÁV̌̌R}

Pokud má být psychologická intervence u sportovců efektivní, musí být prováděna individuálním, systematickým př́stupem, postupně. Měla by obsahovat různé psychologické techniky integrované v jednotném programu. Co se týče samotného nácviku imaginace, měl by psycholog sportovce vést především $\mathrm{k}$ tomu, aby se cítil co nejvíce jako při reálném vykonávání pohybu. To znamená zapojit do představy všechny smysly, ale také emoce a tělesné pocity. Důležitá role psychologa v této fázi spočívá především v motivování sportovce, jelikož celý nácvik imaginace a jejího procvičování záleží na systematickém a především dlouhodobém opakování. Úlohou psychologa je podporovat sportovce $\mathrm{v}$ dodržování programu imaginace. Úspěšnost imaginace také závisí na tom, jak dobře se tato mentální technika sportovci vysvětlí, jaký význam jí psycholog přikládá a jak techniku umí sportovci předat.

\section{LITERATURA}

Crust, L. (2005). Sport Psychology - the will to win. London: Peak Performance Publishing.

Driediger, M., Hall, C., \& Callow, N. (2006). Imagery use by injured athletes: a qualitative analysis. Journal of Sports Sciences, 24(3), 261-272. [Dostupné též z databáze SPORTDiscus, cit. 2013-02-08].

Hardy, L., \& Callow, N. (1999). Efficacy of external and internal visual imagery imagery perspectives for the enhancement of performance on tasks in which form is important.

Journal of Sport and Exercise Psychology, 21, 95-112. [Dostupné též z databáze SPORTDiscus, cit. 2013-0208].

Lynne, E., Hare, R., \& Mullen, R. (2006) Imagery use during rehabilitation from injury. Journal of Imagery research in sport and physical activity. [online] [cit. 2007-12-14] Dostupný z WWW: <//www.bepress.com/ jirspa/vol1/iss1/art1>.

Morris, T., Spittle, M., \& Watt, A. P. (2005). Imagery in sport. Champaign: Human Kinetics.

Nakonečný, M. (2004). Psychologie téměr pro každého. Praha: Academia.

Short, S. E., Ross-Stewart, L., \& Monsma, E. V. (2006). Onwards with the evolution of imagery research in sport psychology. Athletic Insight, 8(3), 47-63. [Dostupné též z databáze SPORTDiscus, cit. 2012-11-28].

Short, S. E., Tenute, A., \& Feltz, D. L. (2005): Imagery use in sport: Mediational effects for efficacy, Journal of Sports Sciences, 23(9), 951-960. [Dostupné též z databáze SPORTDiscus, cit. 2012-11-28].

Singer, R., Hausenblas, H., \& Janelle, Ch. M. (2001). Handbook of Sport Psychology. Toronto: John Wiley \& Sons, Inc.

Slepička, P., Hošek, V., \& Hátlová, B. (2006). Psychologie sportu. Praha: Karolinum.

Watt, A. P., Morris, T., \& Andersen, M. B. (2004). Issues in the development of a measure of imagery ability in sport. Journal of mental imagery, 28(3), 149-180. [Dostupné též z databáze PsycINFO, cit. 2010-05-20].

Weinberg, R., Butt, J., Knight, B., Burke, K. L., \& Jackson, A. (2003). The relationship between the use and effectiveness of imagery: An exploratory investigation. Journal of Applied Sport Psychology, 15(1), 26-40.

[Dostupné též z databáze SPORTDiscus, cit. 2012-11-28].

Weinberg, R. S., \& Gould, D. (2003). Foundations of Sport and Exercise Psychology. Champaign: Human Kinetics.

Weinberg, R. (2008). Does imagery work? Effects on performance and mental skills. Journal of Imagery Research in Sport and Physical Activity, 3(1). [Dostupné též z databáze SPORTDiscus, cit. 2012-11-28].

Williams, J. M. (2006). Applied Sport Psychology-Personal growth to peak performance. New York: McGrawHill. 